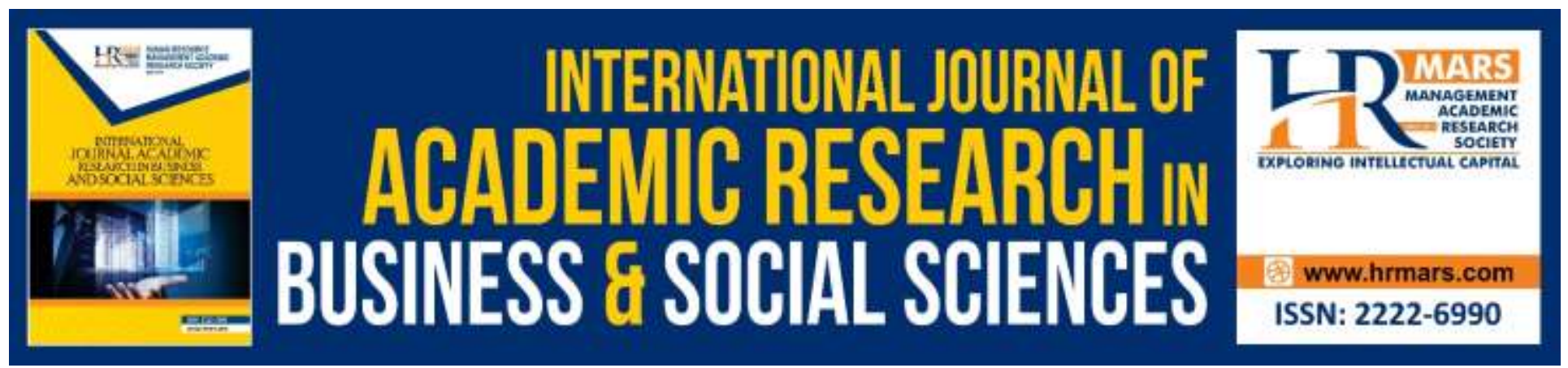

\title{
Improving Pupils' Descriptive Essay Writing Skills with The Use of Email Dialogue Journals
}

Stephanie Ann a/p Thevadas, Harwati Hashim

To Link this Article: http://dx.doi.org/10.6007/IJARBSS/v10-i3/7084

DOI:10.6007/IJARBSS/v10-i3/7084

Received: 06 February 2020, Revised: 20 February 2020, Accepted: 12 March 2020

Published Online: 30 March 2020

In-Text Citation: (Thevadas \& Hashim, 2020)

To Cite this Article: Thevadas, S. A. a/p, \& Hashim, H. (2020). Improving Pupils' Descriptive Essay Writing Skills with The Use of Email Dialogue Journals. International Journal of Academic Research in Business and Social Sciences, 10(3), 698-722.

Copyright: (C) 2020 The Author(s)

Published by Human Resource Management Academic Research Society (www.hrmars.com)

This article is published under the Creative Commons Attribution (CC BY 4.0) license. Anyone may reproduce, distribute, translate and create derivative works of this article (for both commercial and non-commercial purposes), subject to full attribution to the original publication and authors. The full terms of this license may be seen at: http://creativecommons.org/licences/by/4.0/legalcode

Vol. 10, No. 3, 2020, Pg. 698 - 722

http://hrmars.com/index.php/pages/detail/IJARBSS

JOURNAL HOMEPAGE

Full Terms \& Conditions of access and use can be found at http://hrmars.com/index.php/pages/detail/publication-ethics 


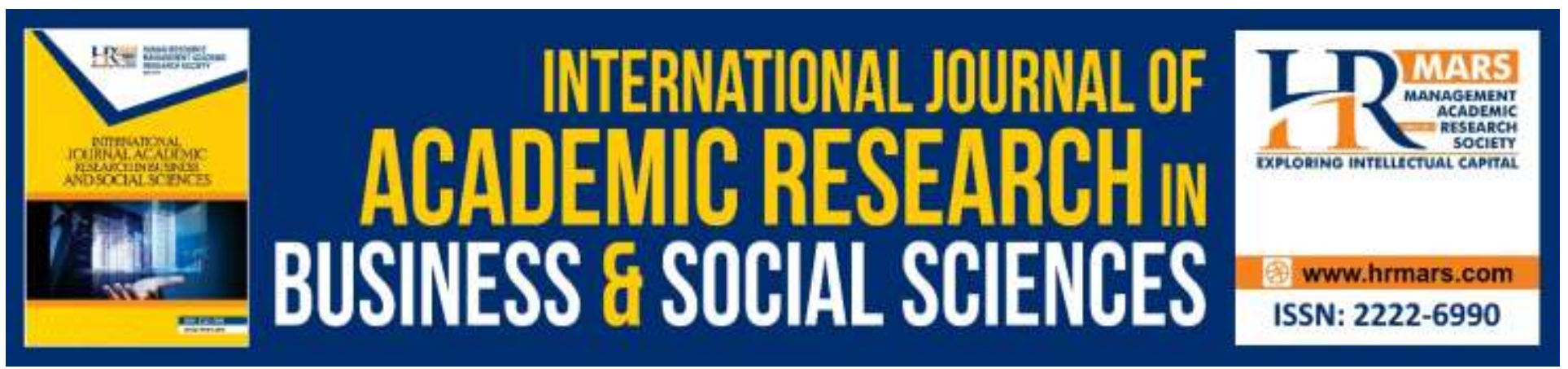

\title{
Improving Pupils' Descriptive Essay Writing Skills with The Use of Email Dialogue Journals
}

\author{
Stephanie Ann a/p Thevadas, Dr Harwati Hashim \\ Faculty of Education, National University of Malaysia, Malaysia \\ Email: annstephanie12@gmail.com, harwati@ukm.edu.my
}

\begin{abstract}
Writing is often perceived as a difficult task among pupils especially in primary schools. Most low and average proficiency pupils lack confidence in writing and are afraid to try to write as they do not know the right grammatical aspect, sentence structure and spelling. This study aims to investigate the use of email dialogue journal in improving pupils' writing skills in descriptive essays. This study is conducted in an urban school in Kuala Lumpur. This study however is limited to those who have internet access at homes. Pupils who were not able to use the internet at homes were provided with opportunities to use the computer laboratories to write their emails. The findings revealed that the pupils are able to improve their writing skills in descriptive essays after using this method over the course of six weeks.
\end{abstract}

Keywords: Writing, Email, Dialogue Journal, Descriptive Essays, Writing Skills

\section{Introduction}

\section{Background of the Study}

Ahangari and Behzady (2011) mentioned that writing is one of the best ways to keep track of learning. Writing is a system for interpersonal communication using visible signs of graphics, symbols on a flat surface such as paper, cloth or even stone slabs. (Nesamalar, 2005). Many pupils are more proficient and fluent in speaking English but when it comes to writing, they tend to deviate from the main topic and make many grammatical errors. Some pupils especially the low achievers are not able to construct a simple sentence with accurate punctuation and spelling. The worst case scenario would be pupils writing essays in examinations that are completely blatant. They do try their best in explaining in written form but the words that are being written do not make sense defeating the whole purpose of the essay.

(The writing course) must provide instructions on how to write a composition. These instructions must be presented step-by-step so that students can, after going through the steps, be able to write a composition. It is important then to provide models of the expected product followed 
INTERNATIONAL JOURNAL OF ACADEMIC RESEARCH IN BUSINESS AND SOCIAL SCIENCES Vol. 10, No. 3, March, 2020, E-ISSN: 2222-6990 @ 2020 HRMARS

by various activities and exercises on grammar and vocabulary necessary to write the composition. Only then should the students be expected to write the composition.(Garis Panduan Menulis Buku Teks KBSM, Kementerian Pendidikan Malaysia, 1986, page 6)

The above excerpt highlights the guidelines that the Ministry of Education has set the objectives in teaching writing in Malaysian ESL classrooms. It can be elucidated that writing involves a handful of steps. Nevertheless, it will produce a good or well written piece of writing. On the other hand, students would want to write with some freedom when it comes to subject of their interest or topics that are not exam oriented. Journal writing would be the best avenue for students to write freely and at the same time sharpen their writing skills subconsciously. The five modes of writing are narration, persuasion, exposition, argumentation and description. This paper focuses on the use of e-mail journal entries to improve pupils' writing skills in descriptive essays. Nesamalar (2005) defined descriptive writing as a detailed account of physical attributes as well as qualities of a person, a thing or a place. It attends to the senses- sight, hearing, smell, touch and taste to convey the whole picture.

Writing is a productive skill whereby an individual expresses his or her thoughts into written form. Peyton and Reed (1990) addressed journal writing as 'communication and language practice'. I could not agree more with this statement because when we write, we automatically are practising our language skill. Some pupils may be fluent in speaking but not in writing. Ergo, writing is the main means of practising the language. Besides, it also serves a communicative purpose as the pupil is 'communicating' by writing them down in the journal.

\section{Statement of Problem}

Among the four skills, writing is regarded as one of the most demanding skills; unlike others, necessitates concentration and constant practice. ESL learners have to struggle with vocabulary, language use, style techniques and sentence formation when creating an essay. (Foroutan, Noordin, Hamzah, 2013). Many a times, Malaysian ESL learners tend to commit errors in terms of grammar, sentence structure, tenses and spelling. The common problem faced by pupils in a Malaysian ESL classroom is they could think what they would express but it would be in their mother tongue which are either Bahasa Malaysia, Tamil or Mandarin and they face difficulties finding or translating the words into English. The product of the essay would read mixed languages, dialogical form in which pupils play in their head and write them directly without paraphrasing into the descriptive form and errors in terms of punctuations and grammar aspects. I have encountered some pupils who tend to not understand the concept of writing in which they used the cue words given, combined them into a few sentences and expect that to be graded in the examination as a full essay.

\section{Objectives of Research}

The objective of this study is to:

- Identify the extent of the use of email dialogue journal in improving pupils' descriptive essay writing skills.

- Improve students' overall writing fluency through the implementation of email dialogue journaling.

- Shed some light as teaching strategy in schools in improving pupils' writing skills. 
INTERNATIONAL JOURNAL OF ACADEMIC RESEARCH IN BUSINESS AND SOCIAL SCIENCES

Vol. 10, No. 3, March, 2020, E-ISSN: 2222-6990 C 2020 HRMARS

\section{Research Questions}

The research question guiding this research is:

i. To what extent does the use of email dialogue journal help in improving pupils' descriptive essay writing skills?

\section{Conceptual Framework}

Dewey's (1938) model served as the conceptual model for this research. Dewey (1938) advocated learning experiences that promote meaningful learning. According to him, effective learning can take place when learners are actively engaged with the content in an extremely personal way. He suggested that experiential learning is an ingenious means to achieve this purpose as learners are highly motivated. He also believed that there was a need for "a theory of experience in order that education may be intelligently conducted upon the basis of experience". We can elucidate here that pupils will involve themselves actively when writing their journal entries as it involves their personal experience. Pupils might feel inferior to write at first due to concerns towards spelling, punctuation and sentence structure but by time, they will gain confidence in writing their journal entries. They will be more excited to share their stories or experiences with the teacher.

\section{Significance of the Study}

This study is conducted to reveal the effectiveness of using email in improving pupils' writing skills. Instead of the usual writing conventions, email is used to engage pupils and gauge their interest as the teacher will communicate with them via email. This study is carried out to help pupils in writing descriptive essays.

\section{Research Gap}

There are many researchers that investigated the use of dialogue journaling to improve pupils' writing skills. However, there are not many that conducted research on the use of e-mail dialogue journal entries in improving pupils' writing skills and especially in the primary schools as most of the researches were conducted in elementary and universities. It is hoped that this research will shed some light on the use of e-mail journal entries among primary pupils in improving their writing skills in writing descriptive essays.

\section{Limitations and Scope of the Study}

This study was conducted in an urban school. Though many pupils have computers and internet access at home, there are still pupils who are from low socioeconomic background. They do not have computers at home. However, I managed to overcome this limitation by allowing the pupils to access the internet at the school computer laboratories during their recess and English period on certain days of the week.

\section{Literature Review \\ Operational Definition}

The terms used in this research are as follow: 


\section{Journal}

Given the importance of reflection, journals are categorized as an important introspective tool based on the process of observing and reflecting on learners' thoughts, feelings, motives, reasoning processes, and mental states influencing behaviour (Nunan 1999, Bailey and Oschner 1983 cited in Bailey et al. 2001). Wong et al. (1995) maintains that reflective journal writing involves a reflective process that is initiated when the learner documents the experience encountered, return to the experience recollects what has taken place and replays the experience and re-evaluation takes place. In other words, pupils jot down their thoughts and experience while recalling those events. When this happens, pupils do not pay attention to the grammatical aspect, spelling or sentence structure, but instead focus is placed on writing them down as they replay the scenarios or experience in their minds.

\section{Email}

Electronic mail or commonly known as email is a digital mechanism for exchanging messages through Internet or intranet communication platforms.

\section{Descriptive Writing}

Nesamalar (2005) defined descriptive writing as a detailed account of physical attributes as well as qualities of a person, a thing or a place. It attends to the senses- sight, hearing, smell, touch and taste to convey the whole picture. Journal entries would aid pupils in producing a descriptive write up. As pupils write, they recall the memories or experiences that they wish to share in the journal. This supports Nesamalar (2005) statement in which descriptive writing attends to the senses.

\section{Writing Skills}

According to Nesamalar et al. (2005), "Writing is a complex skill that involves using visible signs or graphic symbols on a flat surface such as paper, cloth or even stone slabs that makes us a system for interpersonal communication". Pupils may find it hard to write but when they communicate by writing about something that they have experienced, they will slowly catch up the skills of writing.

\section{Past Studies and the Summary Journals as a Teaching and Learning Tool}

According to Mlynarczyk (2013), there are three factors as the most important elements in improving ESL/EFL students' writing abilities: "practice, attitude, and individual tutoring" (p.37). She emphasizes that these three components are central to journal writing: "journals give students extensive writing practice, the opportunity to express and perhaps to change their attitudes toward writing, and the chance to develop a personal relationship with the teacher" (p.36). As the saying goes, "practice makes perfect', pupils improve their writing skills over the course of writing journal entries. They might not realize it at that moment as they pour out their feelings and emotions as they write, but in the long run, they do make progress.

In a study that was conducted by Zahra Hashemia and Tayebeh Mirzaei (2015) to investigate the impact of journal entries on enhancing EFL medical students' reflections, attitudes and sense of self, there was an improvement in both writing style and grammar. These participants had no experience writing journal entries before this study and some of them reported an expanded sense of self and a 
confidence in their capacity to become successful journal writers. From the study also, it was seen that the choice of words used in the journal entries were carefully and clearly explained. The researchers implied the probability of the participants using a dictionary to choose their words. It can be elucidated here how journal writing entries could improve an individual's vocabulary, and in the bigger picture, descriptive writing skills.

A study was conducted at a post-secondary institution by Lew and Schmidt (2007) to investigate the extent to which students believe that journal writing improves their learning. They found that "students' beliefs about the usefulness of journal writing in enabling students to think and write reflectively are related to their beliefs about improving learning through frequent journal writing, and the use of the journal writing as an impression management tool, and as a means to feedback on team work" (p.579). They concluded that using online reflection journals offers numerous opportunities for students to reflect on their learning, and for facilitators to monitor students' progress through their reflections.

Greiman and Convington (2007) examined the journal writing experiences of student teachers to obtain insight into the process of developing reflective practitioners. They found that student teachers were comfortable with writing as a form of communication and many perceived that journal writing went well. The participants came to conclusion that the most frequent benefit of journal writing is reflective thinking.

In another study, Spaulding and Wilson (2002) examined the journals of 34 students. They posited that reflective journal writing can serve four purposes for the student. According to them, journal writing is important for students as it serves as a permanent record of thoughts and experiences, establishes and maintains a relationship with the instructor, provides a safe outlet for frustrations and concerns; and aids internal dialogue.

Williams (2008) investigated the use of reflective journal writing in an 8th grade classroom. Her findings revealed that reflective journal writing created greater class participation, stronger academic achievement and a better opportunity for students to connect with the subject matter.

All these researches prove that journal writing aids pupils in improving their writing skills. Participants also became more reflective thinkers after the journal entries over the period of study. However, most of these studies were conducted on a secondary school level and varsities. Little research had been done among primary school pupils. Most of these studies also used journals in hard copy form instead of a virtual learning experience.

\section{Email as a Fun and Interesting Language Learning Tool}

De Montes and Gonzales (2000) investigated the effectiveness of email in an online course of professional development of K-12 teachers. They found that email allowed the instructor to maintain close relationships with learners and provide ongoing support.

Clingerman and Bernard (2004) conducted a study using email as a supplemental method of supervision in a college counselling practicum course. The email messages were found to have and retain a personalization focus, often reporting personal experiences and feelings with regard to the counselling practicum. Also, they reported email increased the students' thoughtfulness, interest in class, awareness of others' attitudes, and active participation in the class. Based on both the studies, it can be seen that emails are used to make learning writing meaningful in a fun and interesting way. Instead of the usual conventional manner in learning English in classrooms that sometimes may bore 
INTERNATIONAL JOURNAL OF ACADEMIC RESEARCH IN BUSINESS AND SOCIAL SCIENCES

Vol. 10, No. 3, March, 2020, E-ISSN: 2222-6990 C 2020 HRMARS

pupils who prefer varieties in writing activities, the use of ICT and emails may help engage pupils in learning to write better.

\section{Methodology}

This section discusses the methodology which includes the research instruments and its procedures, the validity and reliability,

3.1 Instruments and Procedures

For the purpose of this study, these three instruments were used:

\section{Interview}

The researcher conducted an interview session prior the email dialogue journaling to get pupils' understanding about journal entries. After the research's period of ten weeks, the researcher conducts an interview session with the pupils to get their perception towards email dialogue journaling and how it has impacted them.

\section{Pre- test}

The pre-test a stimulus with some word cues to help pupils write an essay. The vocabularies given are from the Year 5 syllabus from the Ministry of Education. The time allotted for pupils to complete the pre- test is an hour. The researcher administers the test as pupils answer to ensure the validity and reliability of their answers.

\section{Post- test}

The post- test will be of the same stimulus as the pre-test. This is to see how far pupils have improved in the course of ten weeks after the email dialogue journaling with the teacher.

\section{Document Analysis}

I looked into their works done in school during my lessons as I was able to see the immediate work and the words they use when writing. According to Creswell (2014), documents provide valuable information in helping researchers understand central phenomena in qualitative studies. By collecting and analysing the pupils' writing, use of words and register, I would be able to see their vocabulary level. The documents that I will choose to analyse would be:

(i) the pupils' writing book as it will contain the pupils write up either on descriptive writing or sentence building. I will analyse by seeing the choice of words that the pupils use.

(ii) the worksheets/tasks which I gave them during lessons.

\section{Email Dialogue Journal Entries}

The email dialogue journal entries will be carried out over the course of ten weeks. The journal entries that are written weekly were not assigned to any specific theme but were based on the pupils' experience or reflection on what they have done throughout the week. The researcher was careful to not pay much attention to the grammar and punctuation as this study focuses on getting pupils to write. Pupils were simply required to jot down anything they wish to share with the teacher. As pupils emailed their journals weekly, teacher responded by responding and complimenting their write up in the email itself. After the course of ten weeks, a post- test was conducted. 
INTERNATIONAL JOURNAL OF ACADEMIC RESEARCH IN BUSINESS AND SOCIAL SCIENCES

Vol. 10, No. 3, March, 2020, E-ISSN: 2222-6990 C 2020 HRMARS

\section{Reliability of the Instrument}

The figure below summarizes a good interviewing procedure in a checklist adapted by Gay et al. (2005).

A Checklist for Interviewing

- Who will participate in your interview?

- What types of interviews are best to conduct?

- Is the setting for your interview comfortable and quiet?

- If you are audiotaping, have you prepared and tested the equipment?

- Did you obtain consent from the participants to participate in the interview?

- $\quad$ Did you listen more and talk less during the interview?

- $\quad$ Did you probe during the interview? (ask to clarify and elaborate)

- $\quad$ Did you avoid leading questions and ask open- ended questions?

- Did you keep participants focused and ask for concrete details?

- $\quad$ Did you withhold judgements and refrain from debating with participants about their views?

- Were you courteous and did you thank the participants after concluding the interview?

\section{Source: Adapted from Gay et al. (2005)}

\section{Figure 1 A Checklist for Interviewing}

\section{Validity of the pre- test and post- test}

The pre- test and post- test will use a stimulus from the Year 5 textbook. Both pre- test and post- test will display the same stimulus as the findings of research will reveal the improvement of pupils in writing descriptive essay. Ergo, the same stimulus will be used to increase the validity of the findings.

This section discusses the research design, population and sampling, data collection and the analysis of data.

\subsection{Research Design}

The research design that was employed was an action research design. Since this is an education issue, an action research is the most suitable design to be used to collect data. According to Mills (2011), action research designs are systematic procedures done by teachers (or other individuals in an educational setting) to gather information about, and subsequently improve, the ways their particular educational setting operates, their teaching, and their student learning. Thus, this research's findings could be used by other educators to reflect on their current practices and bring about changes among students. Mills (2011) discussed two types of action research designs that are practical action research and participatory action research. The type of research that will be used for this study is the practical action research. According to Schmuck (1997), practical action research is used when educators seek to enhance the practice of education through the systematic study of a local problem and its purpose is to research a specific school situation with a view toward improving practice. 


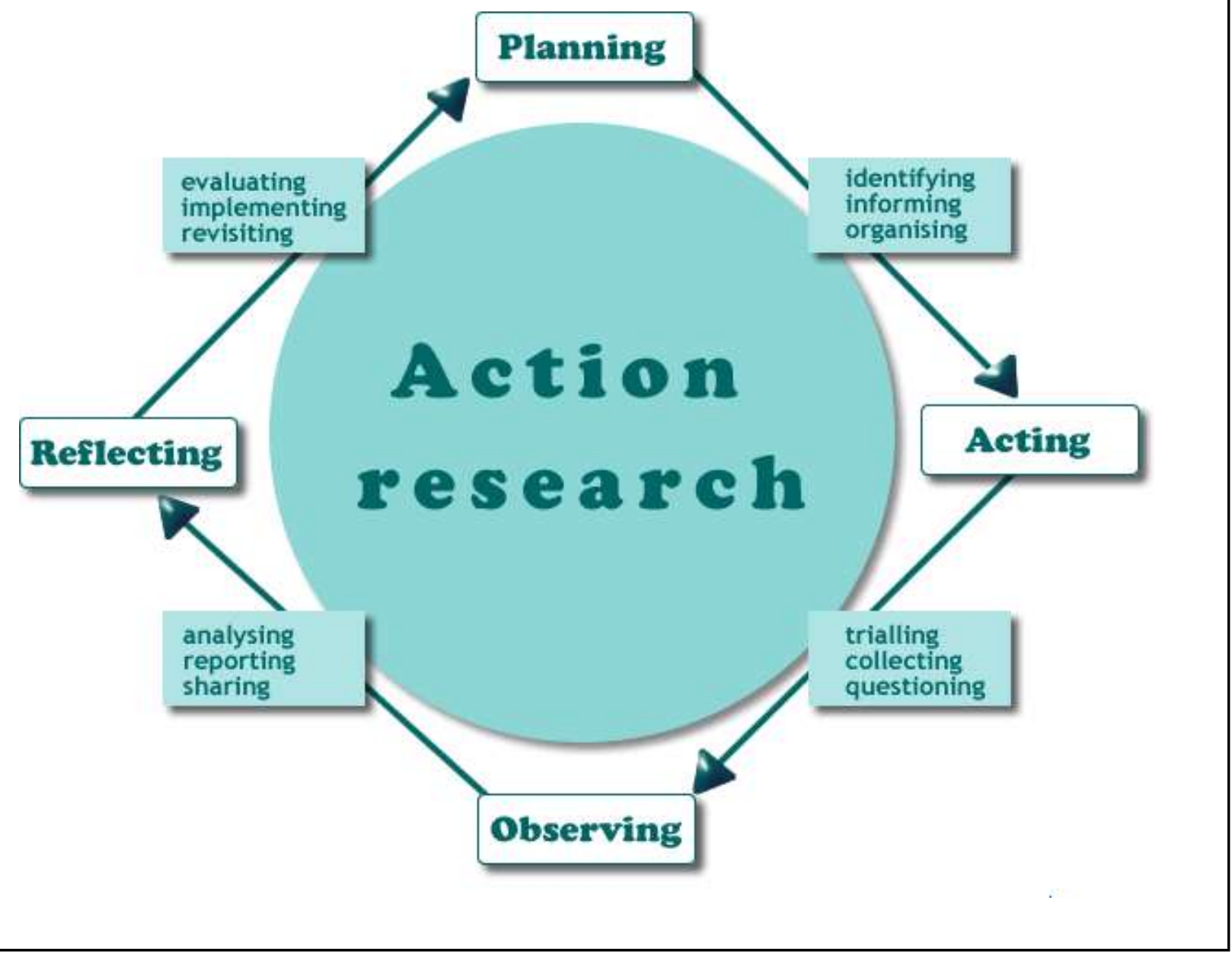

Figure 2 Action research design that was used in this study

First, at the 'Planning' phase, the issue was identified. The researcher also decided on the research title, questions and objectives after identifying the issue. After some readings about past studies and researches, the intervention to be used was decided. At this stage, the planning of instruments was thought of too.

At the 'Acting' phase, a pre- test was conducted to acknowledge pupils' writing skills. Then, the email dialogue journaling was conducted over a period of 10 weeks. After the time frame of 10 weeks, a post- test was administered. An interview session with the pupils was also conducted to know pupils' perception towards how email dialogue journaling has improved their descriptive essay writing skills. In the third phase, 'Observe', the researcher analysed the data collected and identified with the research questions and objectives. At the last phase, 'Reflect', the researcher reflected on the effectiveness of using email dialogue journaling in improving pupils' descriptive essay writing skills. The researcher would also opt for better ways to improve this intervention method based on the research's findings. 
INTERNATIONAL JOURNAL OF ACADEMIC RESEARCH IN BUSINESS AND SOCIAL SCIENCES

Vol. 10, No. 3, March, 2020, E-ISSN: 2222-6990 @ 2020 HRMARS

\section{Population and Sampling}

The sample for this study consists of pupils from a Year 5 ESL classroom. Participants are from the class in which the researcher teaches them English throughout the year.

\section{Data Collection}

A pre- test was conducted prior the email dialogue journal writing. Pupils were also given a brief explanation on how to write journal entries. At the end of the 10-week course of journal writing, a post- test was conducted. An interview session was conducted pre and post email dialogue journaling.

\section{Procedure of Data Collection}

The email dialogue journaling was conducted weekly over the course of ten weeks. The emails that were sent weekly were not assigned to any specific theme but were based on the pupils' experience or reflection on what they have done throughout the week. Pupils were simply required to jot down anything they wish to share with the teacher. After the course of ten weeks, a post- test was conducted. An interview session was conducted to gather information from pupils regarding their perception towards the use of email dialogue journaling and its effects on their descriptive essay writing skills.

\section{Analysis of Data}

The interview findings was analysed based on the checklist in Figure 1 . The researcher audiotaped the interview session so as to not miss any important detail. The researcher also took down notes as the interview took place.

As for the pre- test, the researcher focused on the descriptive writing as a whole instead of paying attention to little details such as the grammatical error, sentence structure etc. At the end of the 10week period, the researcher evaluated the post- test and compared that with the pre- test that the pupils did earlier. The email dialogue journal entries were checked by the researcher weekly as the pupils submitted theirs.

\section{Implementation of Action}

The researcher used email dialogue journaling technique to improve the pupils' descriptive essay writing skills. The researcher explained to pupils how it works so as to not make them unsure of what to write and how to write. Since the pupils are more familiar with ICT in this $21^{\text {st }}$ century, it was easier to explain to make them understand. The problem was to get them to type as in write the email. The writing part is the problem, hence the introduction of this method. The researcher explained that the pupils can talk about anything while dialogue journaling with the teacher. The teacher guided the pupils for the first few entries. After some time, the pupils were able to write themselves as the conversation was on going with the teacher. The struggles in writing were there but they managed to improve over time.

The researcher used this email dialogue journaling technique as it was some form of learning method to attract pupils to write. Pupils are definitely getting bored with the usual writing activity and plus this is to attract the average and below average pupils to write more. 
"Dialogue journals provide regular writing practice in low-stress forum where students are able to express themselves freely as well as see models of quality writing." (Datzman, 2012) Using this as a medium to improve pupils' descriptive essay writing skills, pupils can also increase their selfconfidence while writing. Many a times, pupils wish to write more but are afraid that they go off topic or become too conscious of their tenses, spelling, the correct sentence structure and so on. By using this medium, pupils will not feel the stress as they are not evaluated but instead are practising the language and writing skills. Since the feedback will be given from the teacher, it will somehow boost their confidence level as it is taking place in a non formal manner.

The research was conducted based on the model by Kemmis and Taggart (1988) as shown in the diagram above. It is a cyclical process involving four stages respectively. Below is the brief outline of plan that was conducted during the research.

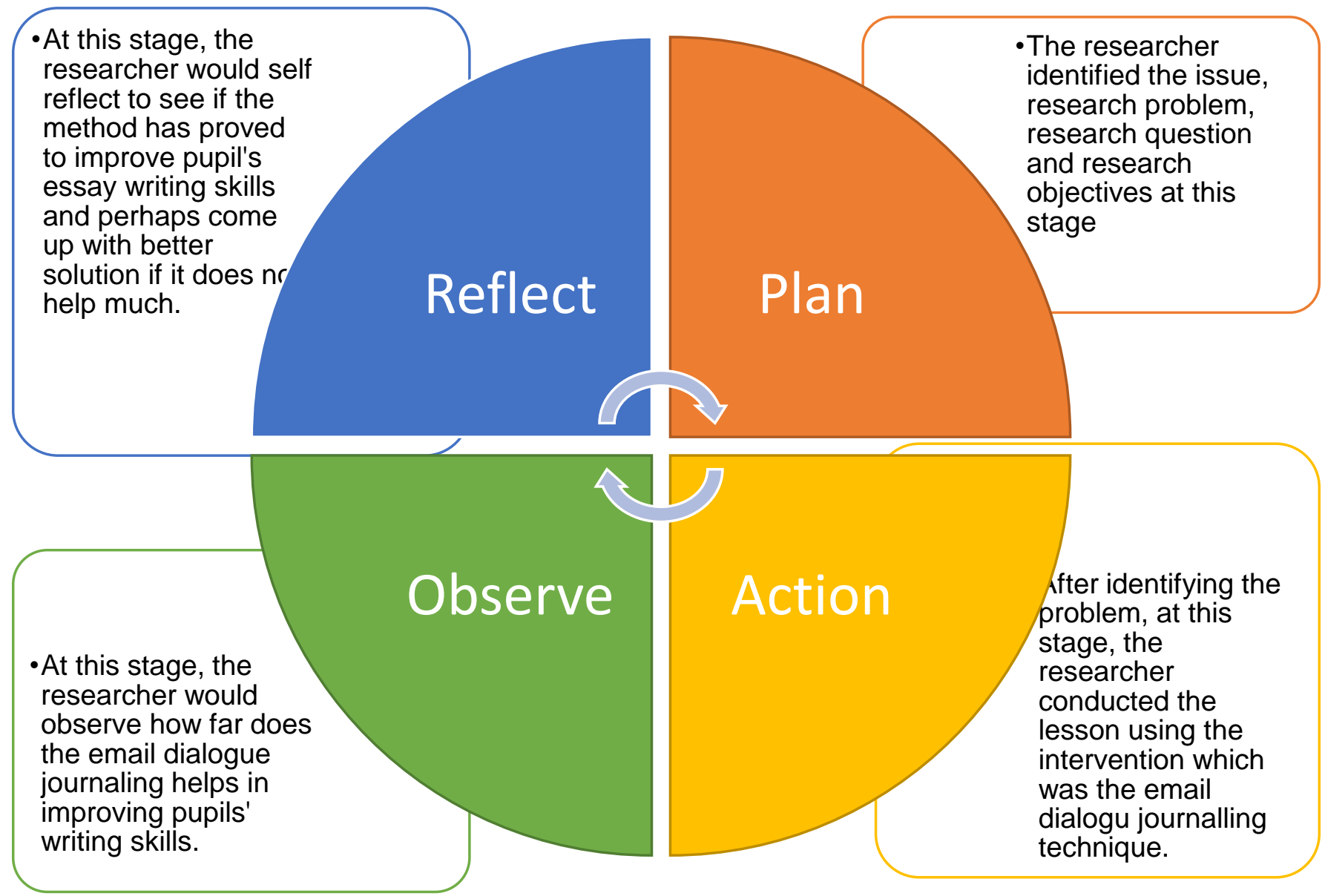

Figure 3 Stages of the intervention based on the AR model

First, at the 'Plan' phase, the researcher identified the issue and did some reading about the issue which was about the poor descriptive essay writing skills among pupils. The researcher also decided on the research title, questions and objectives after the issue has been identified. Then, a few strategies were drafted out to solve the issue and the best and suitable one that is to be implemented was selected to be used to improve their descriptive essay writing skills. At this stage, 
the researcher also planned the instruments that will be used to collect the data. At the 'Action' phase, the researcher conducted a pre-test first to know the level of the pupils. Then the mid-term exam was carried out. Upon seeing the results, the intervention which is the email dialogue journaling technique was brought in and introduced to the pupils. Pupils were clueless about the technique. It was explained clearly and in depth on how it works and how the teacher will help them in replying and assisting at the same time. After the intervention, data were collected from a post test, document analysis and journals. The post test would be of the same questions as the pre test to see if pupils were able to answer the questions after the use email dialogue journaling. As for the document analysis, their daily writing work were collected and analysed. Moving on to the third phase, 'Observe', the researcher observed how the intervention has helped the pupils by seeing the post test results and also the writing that the pupils produce in the daily English lesson. The last phase, 'Reflect', the researcher self reflect on how the intervention that is the use of email dialogue journaling has helped the pupils to improve their descriptive essay writing skills. Upon reflection, it can be concluded that the use of email dialogue journaling did play a role in improving pupils' descriptive essay writing skills.

\section{Data Collection}

The participants for this research were of convenience sampling as the researcher carried out the research on the class that she was teaching. Since the research question was focused on performance measures, a few methods were chosen to collect the data. It would be a methodological triangulation (Balnaves and Caputi, 2004) as it involves using more than one method to collect the data. Among those would be a pre-test, post-test, journal writing, interview, observation and documents analysis.

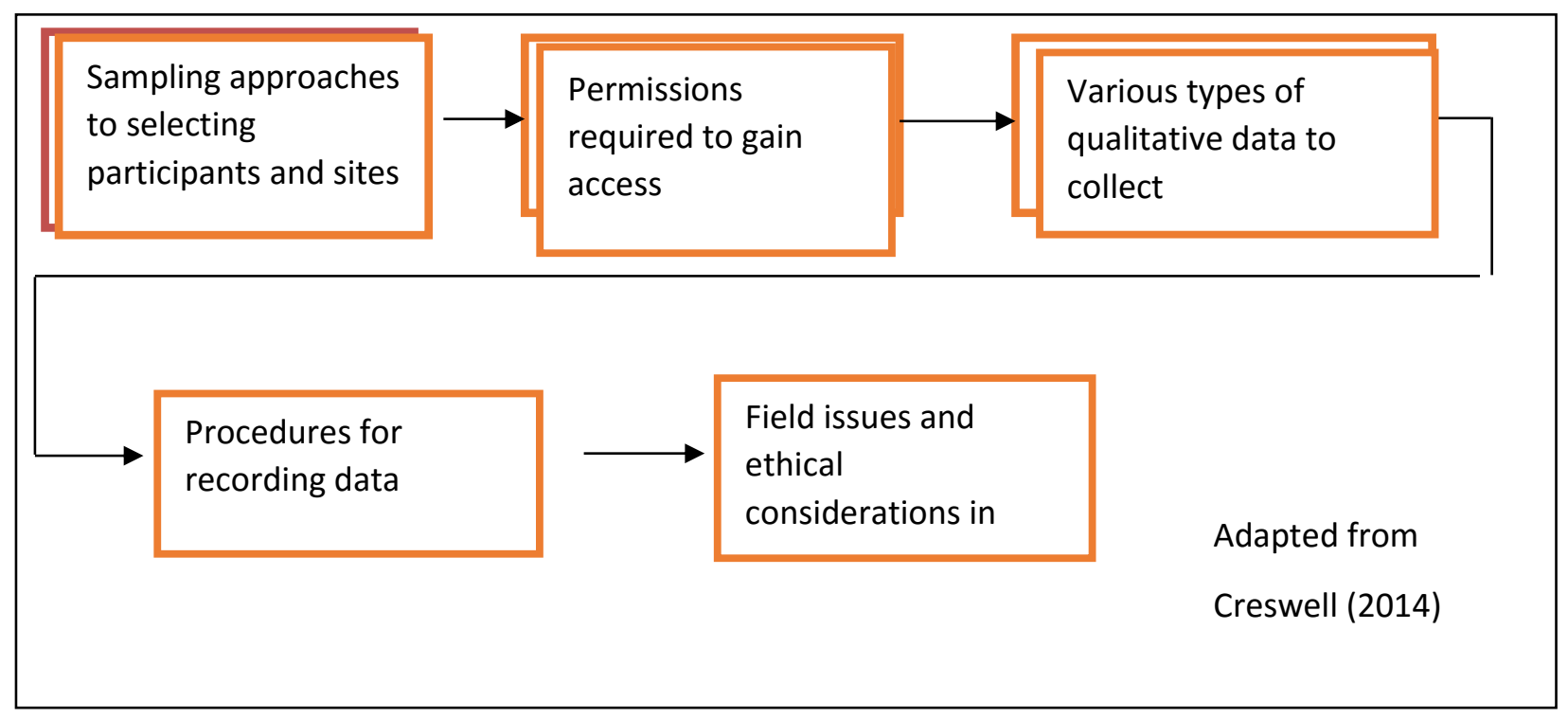

Figure 4 Five process Steps in collecting qualitative data

\section{Email Dialogue Journal}

As for the email journal writing, this is the main source of information to see if pupils could improve their descriptive essay writing skills. The teacher communicates with the pupils via email. At the 
INTERNATIONAL JOURNAL OF ACADEMIC RESEARCH IN BUSINESS AND SOCIAL SCIENCES

Vol. 10, No. 3, March, 2020, E-ISSN: 2222-6990 C 2020 HRMARS

beginning, it could be seen that the pupils were unclear of what to write and how to start writing. The teacher helped by giving prompts during school hours and also related them with the topic learnt on that day during the English lesson. For example, topics about "Family Day' and 'Saving, Spending and Sharing'. Therefore, pupils know that they could start with something they are familiar with. The initial process of the email dialogue journal was not that easy for them as they are unsure of the structure and spelling of words. As time passes, their confidence increased and signs of writing improvement could be seen. Though the changes were small, it was gradual and pupils became more active and confident in class during the English lesson. Some even started to speak in the language.

\section{Document Analysis}

The researcher looked into their works done in school during English lessons as the researcher was able to see the immediate work and the words they use when writing. According to Creswell (2014), documents provide valuable information in helping researchers understand central phenomena in qualitative studies. By collecting and analysing the pupils' writing, use of words and register, the researcher would be able to see their sentence structure, syntax, spelling and other mechanics of writing. The documents that the researcher chose to analyse were:

(i) the pupils' writing book as it will contain the pupils write up either on descriptive writing or sentence building. The researcher analysed based on the mechanics of writing and how pupils were able to write descriptive essays.

(ii) the pupils' worksheets/ task sheets that were given during the English lesson. 
Identify the types of documents that can provide useful information that can answer your qualitative research questions

Consider both public and private documents as sources of information for your research

Once the documents are located, seek permission from the appropriate individuals in charge of the materials.

If you ask participants to keep a journal, provide specific instructions about the procedure.
-At this phase, the researcher decided on using the pupils' writing books and the task sheets given in class.
- In terms of private documents, the researcher has the pupils' writing books that are used during English lessons. In terms of public documents, the researcher obtained the recent monthly test paper results as the source of information.
- The researcher asked each individual's permission to hand in their personal document such as their writing books and also their emails which will be handed in virtually.
- Instructions were given on how to write an email dialogue journal. The researcher explains the term 'email dialogue jornal' and how it works both ways with the researcher.
Once you have permission to use documents, examine them for accuracy, completeness and usefulness in answering the research questions for your study
-The researcher looked into the aspects of vocabulary, grammar, spelling, sentence structure and words register the participants used to monitor the improvement of the pupils' descriptive essay writing skills.

\section{Figure 6 Guidelines for collecting data in qualitative research}

\section{Pre-test and Post Test}

A pre test, which was the pupils' mid term examination was carried out. Pupils' essays were analysed to see their level of writing proficiency. Many of them lack the correct sentence structure, grammar, tenses and also the spelling.

The common types of descriptive essay questions would be describing about the holidays, accident, events at schools and other themes that are familiar with the pupils. 
INTERNATIONAL JOURNAL OF ACADEMIC RESEARCH IN BUSINESS AND SOCIAL SCIENCES

Vol. 10, No. 3, March, 2020, E-ISSN: 2222-6990 @ 2020 HRMARS

In the pre test that the researcher conducted, it was focused on words and vocabularies to see the registers that these pupils are familiar with and their level of writing proficiency.

The post test was carried out after the intervention that is the use of email dialogue journaling. This test was given to the participants to see how far the use of email dialogue journals help improve the pupils' descriptive essay writing skills. Two post tests were carried out to test the validity and reliability of the research. The first post test was exactly the same as the pre- test essay question whereas the second post-test displayed a different essay question to see if pupils had really improved in their descriptive essay writing skills.

\section{Observation}

Observation was conducted throughout the research period. The researcher did the observation before the email dialogue journaling technique was conducted, during the process and also after the method has been implemented for about six weeks. Data were collected and were useful in answering the research question. Further details about the data collected during the observation will be discussed in the next section of this paper.

\section{Interviews}

The researcher also conducted a few interviews with some of the pupils who used the email dialogue journaling technique. Their responses were positive towards this method. Some of the pupils were quite happy with their writing after using this email dialogue journaling technique. They can see the difference in their writing and do enjoy writing lessons at school.

\section{Findings}

In order to find out how much email dialogue journal could improve pupils' descriptive essay writing skills, data was collected from the pre and post- tests, interview, observation and document analysis. The findings showed the usefulness of this engaging method in improving pupils' essay writing skills. The findings revealed that about $70 \%$ of pupils showed improvement in their writing after using this email dialogue journal over the course of ten weeks. Pupils' writing samples were taken from their daily writing activities in their essay writing book. Besides, pupils' test scores were taken from their mid-term exam. Many of them performed at an average and below average level. After pupils started using email to dialogue journal with the teacher, improvement could be seen in their daily writing during English lessons. This resulted in the increase of average and above average level in their final exam test scores.

First of all, pupils did show interest when the idea of email dialogue journaling was first briefed to them. They were excited about this new technique and thus could not wait to get started as it was something new to them. Since it involved ICT, they were more into it as pupils today are quite advanced when it comes to technology. Some of them did show signs of lack of clarity as they did not understand exactly how this email dialogue journaling method works. The researcher did translate the language to Bahasa Malaysia to make them understand better.

In the early stages of this research, some pupils were still unsure of what to write in a journal. They also lacked the confidence hence the short email journals received from them. As for the vocabularies and grammatical aspects, they lack a lot but that was not given much focus at the beginning stage as 
INTERNATIONAL JOURNAL OF ACADEMIC RESEARCH IN BUSINESS AND SOCIAL SCIENCES

Vol. 10, No. 3, March, 2020, E-ISSN: 2222-6990 ¿ 2020 HRMARS

the aim of it at that time was to get them to just start typing and communicating via email using the English language.

\begin{tabular}{|c|c|c|c|c|c|}
\hline Pupil Aspect & $\begin{array}{l}\text { Wrong } \\
\text { Spelling }\end{array}$ & $\begin{array}{l}\text { Wrong } \\
\text { Tenses }\end{array}$ & $\begin{array}{l}\text { Wrong } \\
\text { Word Order }\end{array}$ & $\begin{array}{l}\text { New } \\
\text { vocabular } \\
\text { y }\end{array}$ & $\begin{array}{l}\text { Wrong Sentence } \\
\text { Structure }\end{array}$ \\
\hline Pupil 1 & 10 & 8 & 5 & 2 & 5 \\
\hline Pupil 2 & 12 & 8 & 5 & 0 & 5 \\
\hline Pupil 3 & 11 & 8 & 4 & 0 & 5 \\
\hline Pupil 4 & 11 & 7 & 5 & 0 & 4 \\
\hline Pupil 5 & 11 & 6 & 4 & 1 & 6 \\
\hline Pupil 6 & 13 & 7 & 4 & 1 & 5 \\
\hline Pupil 7 & 11 & 6 & 3 & 1 & 5 \\
\hline Pupil 8 & 7 & 6 & 5 & 1 & 5 \\
\hline Pupil 9 & 7 & 6 & 5 & 1 & 5 \\
\hline Pupil 10 & 7 & 6 & 5 & 1 & 6 \\
\hline Pupil 11 & 6 & 6 & 4 & 2 & 6 \\
\hline Pupil 12 & 9 & 6 & 4 & 1 & 6 \\
\hline Pupil 13 & 10 & 8 & 4 & 0 & 7 \\
\hline Pupil 14 & 8 & 8 & 5 & 1 & 6 \\
\hline Pupil 15 & 8 & 7 & 5 & 0 & 5 \\
\hline
\end{tabular}

Table 1 Results of pre test

\begin{tabular}{|c|c|c|c|c|c|}
\hline Aspect & $\begin{array}{l}\text { Wrong } \\
\text { Spelling }\end{array}$ & $\begin{array}{l}\text { Wrong } \\
\text { Tenses }\end{array}$ & $\begin{array}{l}\text { Wrong } \\
\text { Word Order }\end{array}$ & $\begin{array}{l}\text { New } \\
\text { vocabular } \\
\text { y }\end{array}$ & $\begin{array}{l}\text { Wrong Sentence } \\
\text { Structure }\end{array}$ \\
\hline Pupil 1 & 5 & 4 & 3 & 4 & 3 \\
\hline Pupil 2 & 5 & 4 & 3 & 2 & 3 \\
\hline Pupil 3 & 5 & 4 & 3 & 2 & 3 \\
\hline Pupil 4 & 5 & 4 & 4 & 1 & 4 \\
\hline Pupil 5 & 5 & 6 & 4 & 3 & 3 \\
\hline
\end{tabular}


INTERNATIONAL JOURNAL OF ACADEMIC RESEARCH IN BUSINESS AND SOCIAL SCIENCES Vol. 10, No. 3, March, 2020, E-ISSN: 2222-6990 @ 2020 HRMARS

\begin{tabular}{|c|c|c|c|c|c|}
\hline Pupil 6 & 5 & 4 & 3 & 3 & 4 \\
\hline Pupil 7 & 6 & 5 & 3 & 3 & 4 \\
\hline Pupil 8 & 6 & 3 & 4 & 2 & 4 \\
\hline Pupil 9 & 4 & 6 & 4 & 1 & 3 \\
\hline Pupil 10 & 4 & 5 & 4 & 2 & 2 \\
\hline Pupil 11 & 4 & 6 & 4 & 2 & 4 \\
\hline Pupil 12 & 3 & 3 & 3 & 4 & 5 \\
\hline Pupil 13 & 6 & 6 & 2 & 1 & 5 \\
\hline Pupil 14 & 4 & 5 & 4 & 3 & 4 \\
\hline Pupil 15 & 2 & 6 & 4 & 2 & 4 \\
\hline
\end{tabular}

Table 2 Results of post-test 1

\begin{tabular}{|c|c|c|c|c|c|}
\hline Pupil Aspect & $\begin{array}{l}\text { Wrong } \\
\text { Spelling }\end{array}$ & $\begin{array}{l}\text { Wrong } \\
\text { Tenses }\end{array}$ & $\begin{array}{l}\text { Wrong } \\
\text { Word Order }\end{array}$ & $\begin{array}{l}\text { New } \\
\text { vocabular } \\
\text { y }\end{array}$ & $\begin{array}{l}\text { Wrong Sentence } \\
\text { Structure }\end{array}$ \\
\hline Pupil 1 & 4 & 3 & 1 & 3 & 2 \\
\hline Pupil 2 & 4 & 3 & 3 & 2 & 3 \\
\hline Pupil 3 & 4 & 4 & 3 & 2 & 3 \\
\hline Pupil 4 & 5 & 4 & 3 & 1 & 3 \\
\hline Pupil 5 & 2 & 4 & 4 & 3 & 1 \\
\hline Pupil 6 & 4 & 4 & 3 & 3 & 4 \\
\hline Pupil 7 & 4 & 2 & 2 & 2 & 4 \\
\hline Pupil 8 & 3 & 3 & 3 & 0 & 4 \\
\hline Pupil 9 & 3 & 4 & 4 & 1 & 3 \\
\hline Pupil 10 & 3 & 5 & 4 & 2 & 2 \\
\hline Pupil 11 & 3 & 6 & 4 & 2 & 3 \\
\hline Pupil 12 & 3 & 1 & 3 & 3 & 3 \\
\hline Pupil 13 & 5 & 6 & 0 & 2 & 5 \\
\hline
\end{tabular}


INTERNATIONAL JOURNAL OF ACADEMIC RESEARCH IN BUSINESS AND SOCIAL SCIENCES Vol. 10, No. 3, March, 2020, E-ISSN: 2222-6990 @ 2020 HRMARS

\begin{tabular}{|c|c|c|c|c|c|}
\hline Pupil 14 & 4 & 3 & 3 & 0 & 3 \\
\hline Pupil 15 & 3 & 4 & 3 & 2 & 4 \\
\hline
\end{tabular}

Table 3 Results of post- test 2

After the intervention, it is proven that the email dialogue journals did help pupils in improving pupils' descriptive essay writing skills. Pupils could be seen as more confident in their daily writing activities. They paid more attention to the tenses, punctuation, spelling and word choices used. In a way, the feedback from the teacher as the teacher dialogue journals with the pupils helped them in gaining their confidence in writing essays.

Pupils found this as a fun and exciting means of learning to write descriptive essays. Findings from the interviews suggested that most pupils found this method very encouraging and engaging in learning to improve their writing. This shows that the combination of ICT in teaching writing proves to be useful as it improves their descriptive essay writing skills. It is one of the many fun ways in getting pupils to engage themselves in learning writing and also gaining new knowledge at the same time.

\section{Analysis and Interpretation of Data \\ Pre \& Post Test}

The descriptive essay question was about an accident. Pupils were required to write a short essay within $50-80$ words describing the accident. Some cue words were given to help aid the pupils in writing the descriptive essay.

The pre- test required the pupils to match the pictures to the words. As for the post test 1, it was still the same matching activity. The post- test 2 required pupils to write out the words that match the pictures.

\begin{tabular}{|l|l|l|}
\hline Activity & $\begin{array}{l}\text { Number of pupils who scored } \\
\text { below } \mathbf{2 0} \text { marks (10- 18m) }\end{array}$ & $\begin{array}{l}\text { Number of pupils who } \\
\text { scored below } \mathbf{1 0} \text { marks }\end{array}$ \\
\hline Pre test & 5 & 10 \\
\hline Post-test 1 & 13 & 2 \\
\hline
\end{tabular}

Table 4 Results of pre- test and post- test 1

A number of 15 pupils participated in this research. Out of the 15, 5 pupils scored marks below 20 in the pre-test. The full mark of the essay was 25 . The pupils scored within $10-18$ marks. The other 10 pupils scored below than 10 marks in the essay question. This brings about 33\% of pupils that scored marks within $10-18$ for the pre-test. As for the scores below 10 marks, the percentage of pupils was $67 \%$.

In the pre- test, out of the 5 pupils who scored below 20 marks, 3 pupils managed to get 13 marks and 2 pupils managed to get 11 marks. As for the 10 pupils who scored below 10 marks, 3 pupils managed to get 10 marks, 4 pupils scored 8 marks and 3 pupils scored 9 marks.

As for the post test 1, 13 pupils scored within 10 - 18 marks. 8 pupils managed to score 15 marks, 2 pupils scored 14 marks and 2 pupils scored 16 marks and one pupil managed to score 18 marks. 
INTERNATIONAL JOURNAL OF ACADEMIC RESEARCH IN BUSINESS AND SOCIAL SCIENCES

Vol. 10, No. 3, March, 2020, E-ISSN: 2222-6990 C 2020 HRMARS

Two pupils scored marks below 10 . One of them scored 9 marks and the other one 10 marks.

The researcher conducted a mini post- test 2 to test the pupils if they had put to use their writing skills in other context which was an essay question that was different than the pre-test and post-test 1. This is to ensure the validity and reliability of the research findings. The findings of the post- test 2 are tabulated below.

\begin{tabular}{|l|l|l|}
\hline Activity & $\begin{array}{l}\text { Number of pupils who scored } \\
\text { below 20 marks (12-18m) }\end{array}$ & $\begin{array}{l}\text { Number of pupils who } \\
\text { scored below 10 marks }\end{array}$ \\
\hline Pre test & 5 & 10 \\
\hline Post-test 2 & 14 & 1 \\
\hline
\end{tabular}

Table 5 Results of pre-test and post-test 2

In the post-test 2, 14 pupils scored marks within the range of $12-18$ which makes up to $93 \%$. Only 1 pupil scored below 10 marks which makes up to 7\%. That pupil managed to score 10 marks out of 25 marks.

In the post test 2, 14 pupils scored marks below 20. 9 pupils managed to score 15 marks. 3 pupils scored 16 marks and 2 pupils scored 18 marks. One pupil managed to score 10 marks in the post test 2.

The difference could be seen in the post test 1 and post-test 2 . The number of pupils who scored within the range of $10-18$ marks increased. The number of pupil who scored below 10 marks decreased. Though no pupils scored above 20 marks for the essay, this is still a huge improvement considering the fact that these pupils were initially average and below average pupils and some did not even enjoy writing. 


\section{A Comparison of Results of Pre test and Post test 1}

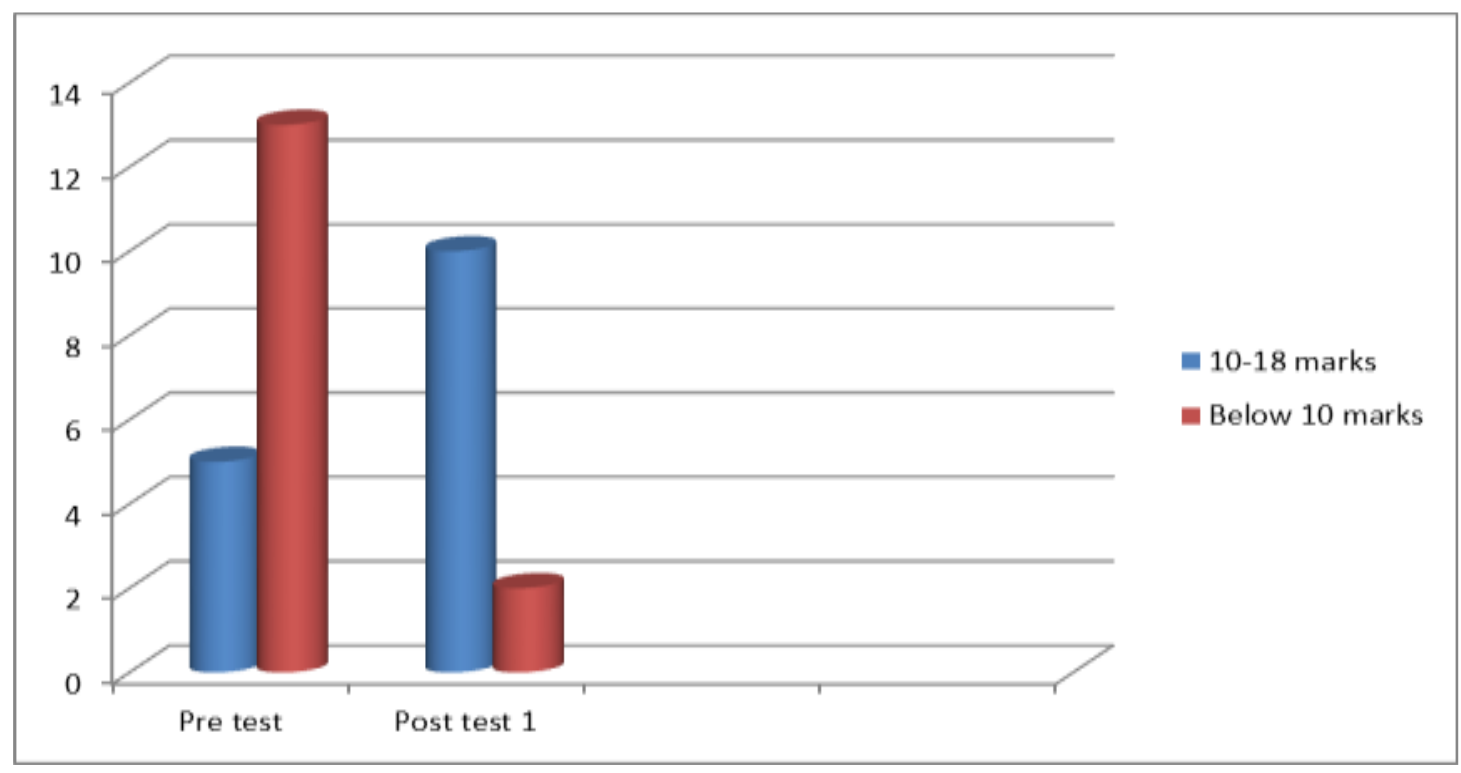

On the second day, a different text was given. This time, the vocabularies chosen were a little difficult compared to the previous ones. The same method was used that is the use of five picture cards to illustrate the vocabularies. The same instructional methods were used too, whereby, first, I showed them the picture card of The Leaning Tower of Teluk Intan. The words that were showed as visuals are 'leaning', 'storeys', 'bricks', 'wood' and 'water tank'.

I elicited some responses from the pupils. Many of them could not tell me that it was a tower. I tried to use more cues to get them to answer.

The essay topic given was about an accident. A few key words were given to help aid pupils in answering the essay. A picture stimulus was given too. This is common as it is the format of the writing section in the UPSR, a national exam which pupils have to sit at the end of their 6 years of primary schooling. The key words given were 'accident', 'ambulance', 'car', 'school' and 'relieved'.

Based on the pre-test, pupils were unsure of how to put ambulance in a sentence using the correct sentence structure. One pupil wrote this, "came a ambulance to help boy'. It can be seen here that the idea is there, but the sentence structure and article used were incorrect. But the pupil has got the rough idea. 
INTERNATIONAL JOURNAL OF ACADEMIC RESEARCH IN BUSINESS AND SOCIAL SCIENCES Vol. 10, No. 3, March, 2020, E-ISSN: 2222-6990 @ 2020 HRMARS

Another pupil wrote 'A boy walking to school. He see accident. He called ambulance. Safe school. Happy.' It could be seen that the tenses were missing and wrong tense was used too. Instead of 'was walking', the pupil wrote 'walking'. Instead of 'saw an accident', the pupil wrote 'see accident'. The phrases 'safe school' and 'happy' were incomplete. It could be seen that the pupil did not know how to make complete sentences using the given key words. That was all the pupil wrote. The pupil wrote an essay that was less than 15 words and carries 25 marks. This is how pupils lose marks in their writing section. Many pupils wrote something like that. Hence, the high number of pupils who scored marks below 10, which was 10 pupils.

In the post-test 1 , slight improvement could be seen when 13 pupils managed to score marks between the range of $10-18$. Only two pupils scored marks below 10 . In the post test, which was the same question as the pre-test, it could be elucidated that pupils knew how to write at least a few simple sentences with minor spelling errors here and there. The sentence structures were not so perfect, but it did improve from the pre-test. The number of words in the essay also increased though it was not within the word limit which was 80-100 words. It can be concluded that pupils did put their effort in the post-test 1 . They seem to remember all the meanings of key words given but when they apply them in the sentence, they tend to get the structure wrong as they miss out the correct tenses. For that purpose, a post-test 2 was conducted to further see if the pupils can still write but in a different context.

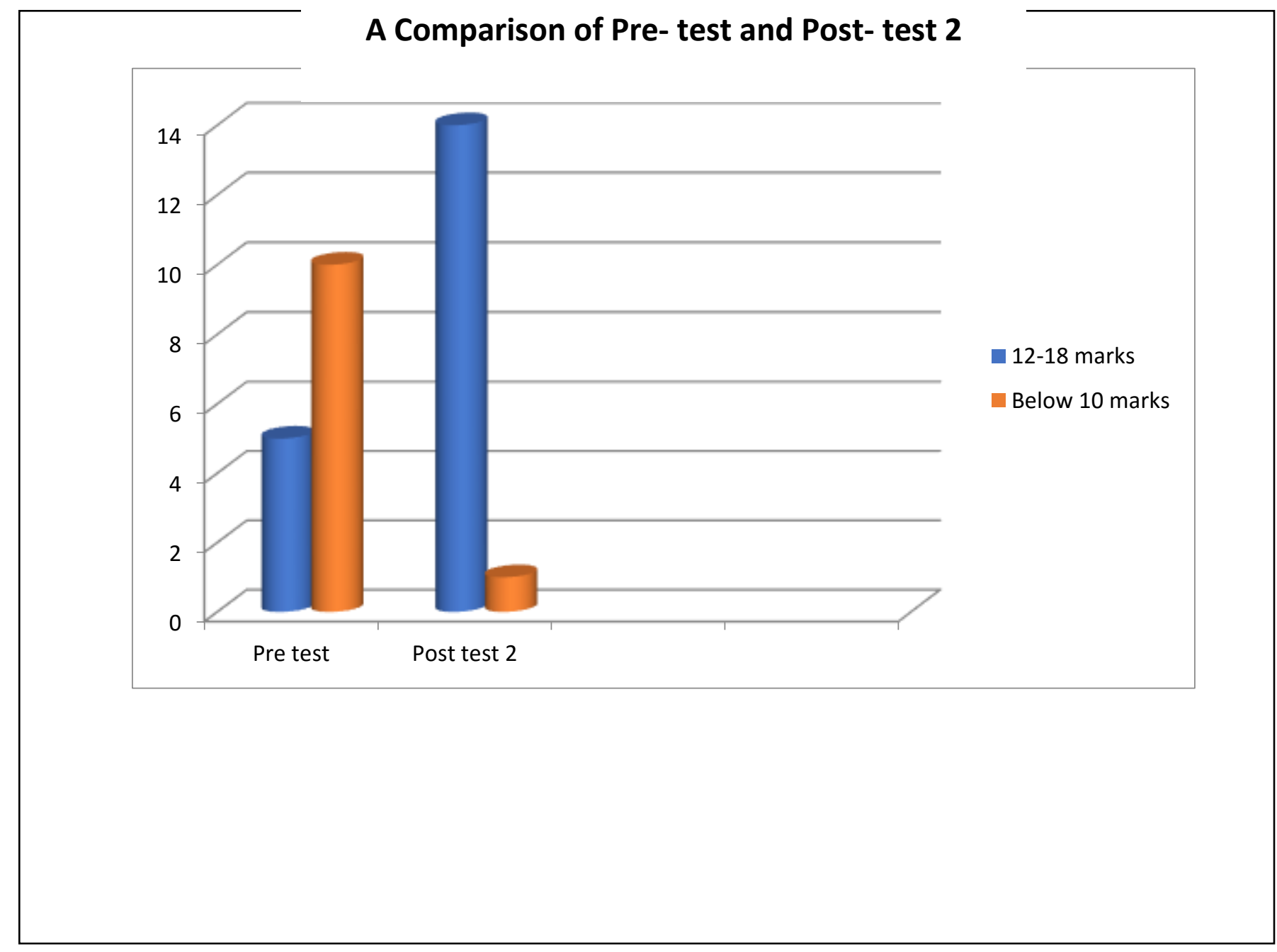


INTERNATIONAL JOURNAL OF ACADEMIC RESEARCH IN BUSINESS AND SOCIAL SCIENCES

Vol. 10, No. 3, March, 2020, E-ISSN: 2222-6990 C 2020 HRMARS

"The weather was very hot."

From the above examples, it can be seen that pupils could grasp the correct sentence structure, spelling and tenses. In Example 3, it can be observed that the pupil used new vocabularies which were 'weather' and 'hot'. That is a good start as the pupil is starting to use new and learnt vocabularies in her writing. This is from a below average pupil. It can be seen that the pupil did learn few new vocabularies although they were simple ones. The pupil also managed to get the spelling of words right. This is not easy especially to get a simple sentence right without any errors.

\section{Interview}

An interview was conducted and an audio recording was recorded to see pupils' thoughts and perceptions on the use of email dialogue journaling in helping to improve their descriptive essay writing skills. A number of 5 participants were involved in this audio recording. The researcher prompted with some questions and the pupils gave some feedback on how the email dialogue journaling helped them in their daily writing. Below are two audio transcriptions recorded from two pupils respectively.

\section{$\underline{\text { Transcription } 1}$}

Researcher: How was your writing before this? Did you enjoy writing?

Pupil 1 : I did not like writing.. (pause).. I get low marks every time.

Researcher: How do you feel now after using this email dialogue journaling technique?

Pupil 1: I improved in my writing. I also like to use the computer.

Researcher: Is it an interesting method for you to learn and improve your writing essay skills?

\section{Transcription 2}

Researcher: How was your writing before this? Did you enjoy writing?

Pupil 1 : I like writing....but.. I don't do well in exams.

Researcher: How do you feel now after using this email dialogue journaling technique?

Pupil 1: I feel happy with my marks. I can write better also.

Researcher: Is it an interesting method for you to learn and improve your writing essay skills?

Pupil 1: Yes! I am happy because my writing has improved.

\section{Observation}

The researcher also used the observation method to collect data for this research. It can be seen that pupils were more passive during the English lessons in classroom and lack the confidence before the email dialogue journaling technique was introduced to them. They were afraid to give answers or speak using the English language during the lessons. As for the writing, some tend to write short responses as they are afraid of making errors. 
After the use of the email dialogue journaling technique, it can be elucidated that pupils were more active in class. They became active learners and were not afraid to volunteer to come forward and write answers on board when it came to writing simple sentences. Improvement can be seen to when the pupils were willing to help their friends when it comes to writing activity in the classroom.

As for their writing, they tend to write more during the writing lesson. They were not afraid of making mistakes. The practise of using the email dialogue journaling technique had made them to be more confident language users in terms of writing and speaking.

At the beginning stage, they were very shy to use the language or even come forward to write on board. As time passed by, they would volunteer when no one else did to come forward and write simple sentences on board. This practice of constructing simple sentences on board was something that their English teacher does before the English lesson starts. A picture will be pasted in front on the white board and pupils were required to construct at least one simple sentence about it. They will have to write the sentence down in their English writing books. The teacher will then randomly pick two to three pupils to come forward and write their sentences on board for all to see. This is also done so as to allow the teacher to correct the errors and explain to pupils about it.

As the email dialogue journaling technique was taking place during the six weeks, the English lessons continued in class as per usual. But this time, when the teacher pasted the picture in front for pupils to construct sentences and later call out a few to display their answers on board, a few pupils actually did volunteer themselves. There were minor errors at first, but the email dialogue journaling technique did prove to boost their confidence level. From increasing their confidence level, it slowly improved their writing skills as well resulting in better performance when they write their descriptive essays in exams.

\section{Conclusion}

The findings revealed that about $70 \%$ of pupils showed improvement in their writing after using this email dialogue journal over the course of six weeks. Pupils' test scores were taken from their midterm examination in May. Many of them performed at an average and below average level. After pupils started using email to dialogue journal with the teacher, improvement could be seen in their daily writing during English lessons. This resulted in the increase of average and above average level in their final term test scores.

This answers the research question in which how far does the email dialogue journal technique help in improving pupils' descriptive essay writing skills. The increase in their test scores was the major proof. Some of the pupils managed to answer the essay questions moderately well with minor errors. Though some of the pupils' test scores were not very high, but there was an increase in their essay writing scores.

Teachers on the other hand, must commit themselves as time to time they have to reply the pupils' email so as to improve their writing skills. Constant support and responses from the teachers help in this research too as pupils learn their mistakes and errors as teachers constantly communicate with them via the email dialogue journaling technique.

\section{Discussion}

Writing has not been an easy task for most pupils especially those of below average level and those who find it difficult to pass in their English subject. However, writing could be made interesting when 
appropriate methods are used to engage pupils to make it a fun way of teaching and learning. Pupils are so used to the conventional writing exercises and activities given at school or as their homework. Internet, on the other hand is something that pupils in this 21st century are familiar with. Pupils will be able to use the internet for a meaningful and educational purpose. In this modern age with technology and era of gadgets, young people use social media such as Whatsapp, Facebook, Twitter, Instagram and more as a platform to communicate. They will also have the sense of accomplishment when they learn and start writing emails and communicate with the teacher. This, in turn boosts their confidence in writing as well. Pupils who are of average level of the English language proficiency may take the extra effort to look meanings of certain words in the online dictionary while they are writing their emails. This encourages self learning at the same time. Their vocabularies will expand and levels up their confidence in using new words in their writing.

According to Harmer (2001) "is one the things students expect from the teacher: an indication of whether or not they are getting their English right" (p. 59). As the teacher constantly communicate with them via this platform when they dialogue journal, pupils will feel the sense of achievement as they improve themselves from time to time based on the teacher's remarks. Based on the findings from this research, it is proven that the pupils did find this method helpful in improving their descriptive essay writing skills. The interview with pupils that was audiotaped further proves that pupils find this email dialogue journaling technique as a beneficial tool in helping them to write and also to gain confidence towards the language.

From this research, it can be elucidated that the email dialogue journaling method did help improve pupils' descriptive essay writing skills. It also gave a positive impact on the pupils. Pupils find this method helpful in their daily writing activities. Hopefully this research managed to shed some light on ways to improve pupils' descriptive essay writing skills.

\section{Recommendations}

This study could also be extended to other language subjects. It could be a fun way in mastering the language through writing by using a platform which is widely used by pupils today. Pupils spend most times on their laptops and tabs at homes, so why not make those times as learning in a fun and educational time? This is a method that most probably will interest many pupils as they get to use ICT. As for the weaker pupils who do not even know the English language at all, perhaps the teacher could start with the Bahasa Malaysia language at first just to give them the rough idea on how this email dialogue journal technique. Once they are used to it, the teacher can slowly start to dialogue journal in English with them. Although the word count may not be many, but at least it will be off to a good start.

As for those who are proficient in English but lacking in the Bahasa Melayu language could use this method to improve their writing skills in that language as here in Malaysia, the main two languages used are English and Bahasa Melayu. It can be seen how this email dialogue journal technique could be extended to the other language subjects for pupils to improve their writing skills. This could result in pupils' interest in writing and also an avenue for pupils to practise their writing skills in different languages that they would want to improve.

This research could also be extended to teachers or teacher trainees who would want to practise their language writing skills. This could be done among peers. Some teachers who are newly posted in schools tend to get subjects that they are not majoring in to teach. Some lack the confidence to 
INTERNATIONAL JOURNAL OF ACADEMIC RESEARCH IN BUSINESS AND SOCIAL SCIENCES

Vol. 10, No. 3, March, 2020, E-ISSN: 2222-6990 C 2020 HRMARS

teach the subject as they are not majoring in that particular language. This is where the email dialogue journal could help them as they communicate with their peers who may be proficient in that language.

\section{References}

Al-Anis, H. M., Karunakaran, T. (2013). Second Language Acquisition: Issues and Implications. International Journal of English and Education, 2(2), 174-182.

Burton, J. (2005). The Importance of Teachers Writing on TESOL. Teaching English as a Second or Foreign Language, 9(2), 1-18.

Cahyono, B., Widiati, U., Prayogo, J. (2017).The Effect of Meaning-focused Feedback as well as Language-focused Feedback in Journal Writing on Indonesian EFL Students' Writing Ability. International Journal of English and Education, 6(4), 103-113.

Chitravelu, N., Sithamparam, S., Choon, T. S. (2005). ELT Methodology Principles and Practice 2nd edition. Shah Alam, Malaysia: Oxford Fajar.

Cole, J., Feng, J. (2015). Effective Strategies for Improving Writing Skills of Elementary

English Language Learners. Chinese American Educational Research and Development Association Annual Conference, (pp. 2-24). Chicago.

Creswell, J. W. (2015). Educational Research: Planning, Conducting and Evaluating Quantitative and Qualitative Research. Edinburgh Gate, Pearson Education Limited.

Farrah, M. (2012). Reflective Journal Writing as an Effective Technique in the Writing Process. An - Najah Univ. J. Res. (Humanities), 26(4).

Harmer, J. (2011). An introduction to the practice of English language teaching (4th ed.). United Kingdom: Pearson.

Hashemi, Z., Mirzaei, T. (2015). Conversations of the Mind: The Impact of Journal Writing on Enhancing EFL Medical Students' Reflections, Attitudes, and Sense of Self. Procedia - Social and Behavioral Sciences, 199 (3), 103-110.

Lambert, M., Sorensen, T., Elliot, K. (2014). A Comparison and Analysis of Preservice Teachers' Oral and Written Reflections. Journal of Agricultural Education, 55(4), 85-99.

Puengpipattraku, W. (2009). THE USE OF JOURNALS TO DEVELOP GRAMMATICAL ACCURACY IN WRITING. MANUSYA: Journal of Humanities Regular, 12(2), 91-108. 